\title{
Effect of membrane length, membrane resistance, and filtration conditions on the fractionation of milk proteins by microfiltration
}

\author{
A. Piry, ${ }^{\star}$ A. Heino,† W. Kühnl, ${ }^{*}$ T. Grein,‡ S. Ripperger,‡ and U. Kulozik ${ }^{* 1}$ \\ *Technische Universität München, Chair for Food Process Engineering and Dairy Technology Weihenstephaner Berg 1, \\ 85354 Freising-Weihenstephan, Germany \\ †Valio Ltd., R\&D Center, PO Box 30, FIN-00039 Valio, Finland \\ $\ddagger$ Technische Universität Kaiserslautern, Chair of Mechanical Process Engineering, Gottlieb-Daimler-Straße, 67663 Kaiserslautern, Germany
}

\begin{abstract}
We investigated the fractionation of casein micelles and the whey protein $\beta$-lactoglobulin $(\beta-L G)$ of skim milk by crossflow microfiltration $(0.1 \mu \mathrm{m})$ for the first time by a novel approach as a function of membrane length and membrane resistance. A special module was constructed with 4 sections and used to assess the effects of membrane length by measuring flux and $\beta-L G$ permeation (or transmission) as a function of transmembrane pressure and membrane length. Depending on the position, the membranes were partly controlled by a deposit layer. A maximum for $\beta$-LG mass flow through the various membrane sections was found, depending on the position along the membrane. To study the effect of convective flow toward the membrane, membranes with 4 different intrinsic permeation resistances were assessed in terms of the permeation and fouling effects along the flow channel. From these findings, we derived a ratio between transmembrane pressure and membrane resistance, which was useful in reducing the effect of deposit formation and, thus, to optimize the protein permeation. In addition, the fouling effect was investigated in terms of reversible and irreversible fouling and, in addition, by differentiation between pressure-induced fouling and adsorptioninduced (pressure-independent) fouling, again as a function of membrane length.
\end{abstract}

Key words: milk, microfiltration, deposit layer, protein fractionation

\section{INTRODUCTION}

In several studies, microfiltration has been investigated regarding the relationship of flux, wall shear stress, and fouling, particularly in the area of protein fractionation as a function of overall membrane properties and average processing conditions (Marshall et

Received February 20, 2011.

Accepted October 2, 2011.

${ }^{1}$ Corresponding author: ulrich.kulozik@wzw.tum.de al., 1993; Brans et al., 2004). Gésan et al. (1994) established a relationship between membrane resistance against water permeation and the fouling behavior for filtration of whey. The higher the initial water flux, the more pronounced the extent of deposit formation. In a subsequent study, Gésan-Guiziou et al. (2002) assessed critical flux conditions for the filtration of latex suspensions as a function of membrane pore size and permeation resistance of the clean membrane. They concluded that a more homogeneous pore size distribution could improve the filtration performance. It is known that low transmembrane pressures reduce the extent of fouling and that fouling affects the transmission of whey protein (Le Berre and Daufin, 1996; Samuelsson et al., 1997; Carić et al., 2000).

Vadi and Rizvi (2001) compared a standard crossflow process with a uniform transmembrane pressure process and concluded that pressure loss along the membrane is responsible for the greater fouling in nonuniform crossflow processes. They argued that fouling could be minimized by decreasing the length of the membrane because of the reduced inconsistent pressure conditions along the membrane surface. This, however, would be at the expense of membrane surface area. The effect of membrane length on the filtration process has hardly been investigated experimentally as a real function of membrane length so far. Therefore, the effect of membrane length and, based on position, the effect of processing conditions in terms of transmembrane pressure and deposit formation is still not sufficiently understood. Furthermore, the correlation between the transmission of whey proteins and membrane fouling has not been assessed as a function of membrane length. In many studies, certain retention of whey proteins was observed, even under low fouling conditions, although Le Berre and Daufin (1998) showed that the whey proteins in milk can pass through a $0.1-\mu \mathrm{m}$ membrane unhindered when there is no strong fouling. Piry et al. (2008) examined an unhindered whey protein transmission near the membrane outlet in their length-dependent studies. The relevance of the length effect is of general interest for the development of membranes for 
specific applications, in particular for the development of an appropriate membrane resistance for gradient membranes. Such membranes are being manufactured in two ways, either with a porosity gradient of the support layer (Garcera and Toujas, 2002) or by changing the thickness of the selective layer along the membrane channel (Grandgeon et al., 2006). Although it is still common practice that membranes are characterized and selected for certain applications based on nominal pore size and maximal water flux, this practice may not be appropriate for applications where deposit formation is mainly influenced by the initial water flux during the change over phase to milk. The transmembrane pressure decreases from membrane inlet to outlet, which results in an inhomogeneous flux along the membrane. Piry et al. (2008) showed that large areas of tubular ceramic microfiltration (MF) membranes with a length common in industry $(1.2 \mathrm{~m})$ are normally operated under deposit layer-controlled filtration conditions during milk filtration. For membrane-controlled filtration processes, the flux value is proportional to the ratio of transmembrane pressure and membrane resistance, according to Darcy's law. This means that by using higher membrane resistances, the critical transmembrane pressure shifts toward higher values and, therefore, toward the membrane inlet (Kühnl et al., 2008). This influences in a decisive manner the objective of a targeted fractionation of proteins from milk by MF.

In this study, permeate flux and $\beta-L G$ transmission characteristics for the MF of skim milk were experimentally investigated as a function of membrane length and membrane resistance under different process conditions. The casein fraction should be retained and the whey protein fraction should pass through the membrane. Although in previous studies, membrane resistance was varied by changing the membrane pore size (GésanGuiziou et al., 2002), membrane porosity (Kuiper et al., 2000), or pore shape (Bromley et al., 2002), irrespective of membrane length, the membrane resistance in this study was varied by changing the thickness of the membrane's selective layer and by measuring flux and protein transmission in 4 successive membrane sections. To our knowledge, this is the first time that membranes with different resistances but the same nominal pore size were experimentally compared as a function of flow path length. Assuming that the critical flux $\left(\mathbf{J}_{\text {crit }}\right)$ is not affected by the membrane resistance as found by Gésan-Guiziou et al. (2002), higher membrane resistance $\left(\mathbf{R}_{\mathrm{M}}\right)$ should result in higher values for the critical transmembrane pressure difference $\left(\Delta \mathbf{p}_{\mathrm{TM}, \mathrm{crit}}\right)$ and, therefore, in reduced deposit layer formation. Another hypothesis is that the length-dependent investigation of the filtration process should reveal a reduction of the deposit layer-controlled membrane area by increas- ing the membrane resistance. Whereas former studies focused on the investigation of critical flux only, the dependency of critical and limiting flux is investigated as a function of membrane resistance in this study. The expected outcome was that fractionation of casein and whey proteins could be optimized in terms of maximizing the whey protein transmission by minimizing deposit layer formation across the entire membrane length. Furthermore, the distribution of pressuredependent and adsorptive (i.e., pressure-independent fouling) as well as reversible and irreversible fouling was investigated. Reversible and irreversible fouling were differentiated by comparing the water flux after rinsing and after chemical cleaning, respectively. For direct comparison of the milk protein fractionation results, membranes with different resistances were compared as a function of initial water flux.

\section{MATERIALS AND METHODS}

\section{Filtration Fluids}

Pasteurized $\left(71^{\circ} \mathrm{C}, 20 \mathrm{~s}\right)$ skim milk $(\mathrm{pH} 6.7 \pm 0.05)$ obtained from a local dairy was used for the filtration trials. The mean total protein content was $3.5 \pm 0.15 \%$ measured with a total protein analyzer (FP 528, Leco, Mönchengladbach, Germany). For the casein micelles, the main milk protein fraction, an average hydrodynamic diameter of $165 \pm 6 \mathrm{~nm}$ and a $\zeta$-potential of -20 $\pm 2 \mathrm{mV}$ at $\mathrm{pH} 6.7$ and $20^{\circ} \mathrm{C}$ were determined (Malvern Nano ZS, Malvern Instruments Ltd., Malvern, UK).

Demineralized tap water with a conductivity of 680 $\mu \mathrm{S} / \mathrm{cm}$ was used for rinsing and cleaning (Inlab 730, Mettler-Toledo GmbH, Giessen, Germany) the filtration equipment. The filtration unit was cleaned in a 3-step procedure with (1) 1\% Ultrasil 14 caustic (Ecolab, Düsseldorf, Germany), (2) $0.5 \% \mathrm{HNO}_{3}$ (Staub \& Co., Nürnberg, Germany), and (3) 0.5\% Ultrasil 14 caustic. The cleaning solutions were diluted with demineralized tap water. Before filtrations, the clean water flux value was determined at $55^{\circ} \mathrm{C}$ using a transmembrane pressure difference $\left(\Delta \mathbf{p}_{\mathrm{TM}}\right)$ of $0.5 \times 10^{5} \mathrm{~Pa}$.

\section{Membranes}

In this study, 4 ceramic monochannel membranes with different hydraulic resistances of the membrane corpus were investigated. These membranes had $\mathrm{ZrO}_{2}$ as selective layer and a nominal pore size of $0.1 \mu \mathrm{m}$ (model D1406, Atech Innovations GmbH, Gladbeck, Germany). The total membrane length was $1.2 \mathrm{~m}$, resulting in a total membrane area $2.2 \cdot 10^{-2} \mathrm{~m}^{2}$. The hydraulic $R_{M}$ was varied by increasing the thickness of the selective membrane layers $\left(\mathrm{R}_{\mathrm{M}}=4.5 \times 10^{11} \mathrm{~m}^{-1}\right.$; 


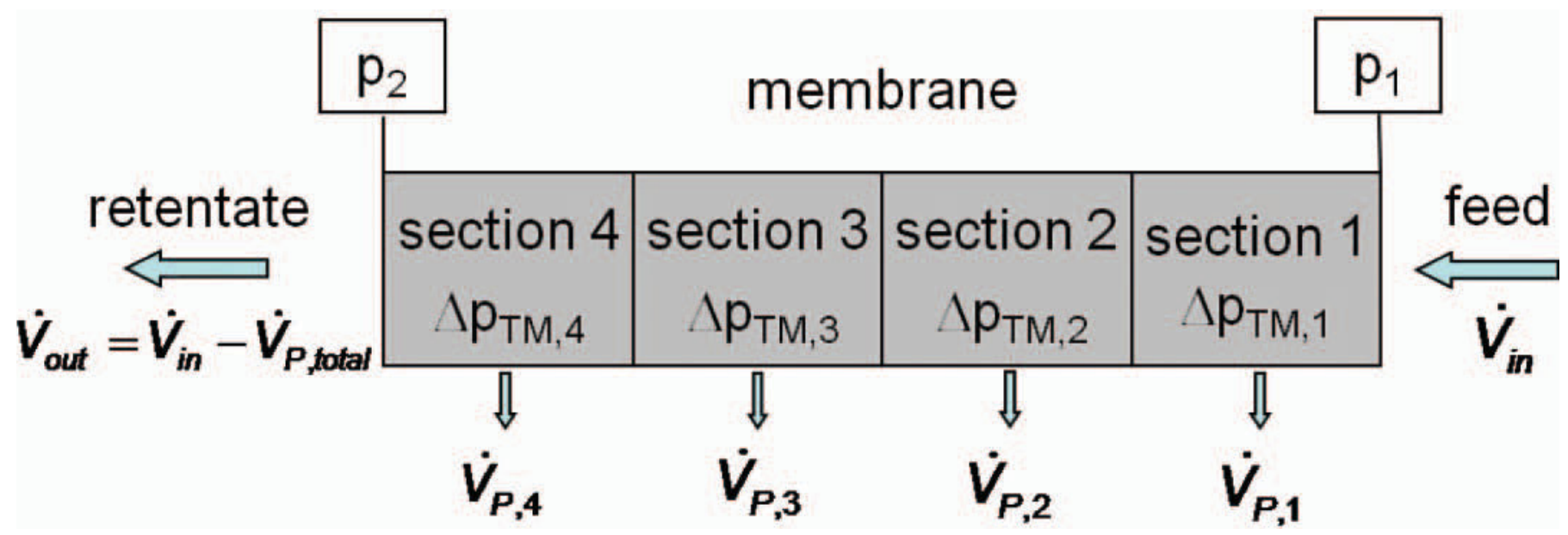

Figure 1. Schematic view of the membrane module. $\mathrm{p}_{1}=$ static pressure at membrane inlet; $\mathrm{p}_{2}=$ static pressure at membrane outlet; $\dot{V}_{\text {in }}=$ volume throughput at membrane inlet; $\dot{V}_{P, x}=$ volume throughput of the permeate in sections 1 through $4 ; \dot{V}_{\text {out }}=$ volume throughput at membrane outlet; $\Delta \mathrm{p}_{\mathrm{TM}, x}=$ transmembrane pressure in sections 1 through 4 . Color version available in the online PDF.

$7.0 \times 10^{11} \mathrm{~m}^{-1}, 8.9 \times 10^{11} \mathrm{~m}^{-1}$, and $\left.14.2 \times 10^{11} \mathrm{~m}^{-1}\right)$. The manufacturer used the same material for the selective layer for the 4 membranes studied. Therefore, the differences in $R_{\mathrm{M}}$ can be attributed solely to changes in the thickness of the selective layer and not by differences in porosity or pore size distribution. Because of the variation in the selective layer thicknesses, the inner diameter of the membranes differed slightly from 5.46 $\mathrm{mm}$ (for the membrane with $\mathrm{R}_{\mathrm{M}}=14.2 \times 10^{11} \mathrm{~m}^{-1}$ ) to $5.95 \mathrm{~mm}$ (for the membrane with $\mathrm{R}_{\mathrm{M}}=4.5 \times 10^{11} \mathrm{~m}^{-1}$ ), resulting in a difference of $245 \mu \mathrm{m}$ of the selective layer thickness. For calculation of the membrane effective filtration area, a mean value for the internal diameter of the different membranes of $5.75 \mathrm{~mm}$ was used. The effect of this simplification on the calculated wall shear stress was negligible.

The thickness of the membrane channel was determined by filling the wetted membrane cut into 4 equal pieces (length $=29.5 \mathrm{~cm})$ with water $\left(\vartheta=20^{\circ} \mathrm{C}\right.$ for both the water and the membrane) and weighing the amount of water fitting into the membrane channel. Because of the high $\mathrm{R}_{\mathrm{M}}$ and the relatively fast measurement procedure $(5 \mathrm{~s})$, the loss of water due to permeation was negligible. With the density of water at $20^{\circ} \mathrm{C}(998.2 \mathrm{~kg} /$ $\mathrm{m}^{3}$ ), the diameter of the inner channel was calculated.

The front side of the porous support layer of each membrane section was sealed at both ends to prevent permeate to flow from one section to another through the porous support of the ceramic material. The membrane sections were then mounted in series in a special module (Figure 1). The distance between 2 successive pieces of membranes was $5 \mathrm{~mm}$, with a smooth connection between the sections. Piry et al. (2008) showed that the set-up using the membranes in 4 sections did not influence the characteristics of the membrane in terms of water flux and filtration performance of skim milk compared with an undivided membrane.

\section{Microfiltration Rig and Operating Procedure}

The microfiltration rig was capable of measuring the permeate flux of each separate membrane section (Piry et al., 2008). The milk filtrations were performed in a batch mode with $20 \mathrm{~L}$ of feed at $55^{\circ} \mathrm{C}$. The milk and the $\mathrm{MF}$ unit were preheated to $55^{\circ} \mathrm{C}$ before the experiment. At first, the water flux and the membrane resistance were determined at $55^{\circ} \mathrm{C}$. At the start of the skim milk filtration, the remaining water was flushed out with the milk until undiluted milk and permeate could be recirculated to the feed tank. Each filtration experiment was conducted over $180 \mathrm{~min}$ at $\vartheta=55^{\circ} \mathrm{C}$ and a wall shear stress $\left(\boldsymbol{\tau}_{\mathrm{w}}\right)=108 \pm 4 \mathrm{~Pa}$ to study the time effect. The mean transmembrane pressure $\left(\Delta \mathbf{p}_{\mathrm{TM}, \mathrm{m}}\right)$ was increased after $90 \mathrm{~min}$ of filtration from $0.50 \times 10^{5}$ to $0.65 \times 10^{5} \mathrm{~Pa}$ and after $135 \mathrm{~min}$ of filtration to 0.80 $\times 10^{5} \mathrm{~Pa}$. At the end of each $\Delta \mathrm{p}_{\mathrm{TM}}$ step, permeate from the 4 sections and retentate were sampled and analyzed for their $\beta$-LG contents. After each filtration, the milk was rinsed out with demineralized water until a stable permeate flux with water was reached. Then, the MF unit was cleaned (clean-in-place process, CIP).

Typically, 2 repetitions were done. The deviations were about $3 \%$ for flux and protein transmission, respectively. The reproducibility of the length-dependent filtration trials was investigated in a more detailed way in a previous study (Piry et al., 2008). 
Table 1. Transmembrane pressures of the 4 sections (S4 to S1) with the corresponding mean transmembrane pressure $\left(\Delta \mathrm{p}_{\mathrm{TM}}\right)$

\begin{tabular}{lcccc}
\hline $\begin{array}{l}\text { Mean } \Delta \mathrm{p}_{\mathrm{TM}} \text { over } \\
\text { whole membrane } \\
\left(\times 10^{5} \mathrm{~Pa}\right)\end{array}$ & \multicolumn{4}{c}{ Calculated transmembrane pressures $\left(\times 10^{5} \mathrm{~Pa}\right)$} \\
\cline { 2 - 5 } & $\mathrm{S} 4$ & $\mathrm{~S} 3$ & $\mathrm{~S} 2$ & $\mathrm{~S} 1$ \\
\hline 0.50 & 0.16 & 0.39 & 0.61 & 0.84 \\
0.65 & 0.31 & 0.54 & 0.76 & 0.99 \\
0.80 & 0.46 & 0.69 & 0.91 & 1.14 \\
\hline
\end{tabular}

\section{Calculation of the Transmembrane Pressures of the Different Sections}

For all filtrations, the same pressure loss across the whole membrane $\left(\Delta \mathbf{p}_{\mathrm{L}}\right)$ of $0.9 \times 10^{5} \mathrm{~Pa}$ was established. The transmembrane pressure of each section $\left(\Delta \mathbf{p}_{\mathrm{TM}, \mathrm{n}}\right)$ was calculated according to equation [1], where $\mathrm{n}$ defines the section of the individual membrane pieces, where $\mathrm{n}=1,2,3$, or $4 ; \mathrm{N}$ is the total number of sections (4); and $\mathrm{p}_{1}$ is module inlet pressure:

$$
\Delta \mathrm{p}_{\mathrm{TM}, \mathrm{n}}=\mathrm{p}_{1}-\frac{(2 \mathrm{n}-1) \cdot \Delta \mathrm{p}_{\mathrm{L}}}{2 \cdot \mathrm{N}} .
$$

In Table 1, the calculated transmembrane pressures of the 4 membrane sections $\left(\Delta \mathrm{p}_{\mathrm{TM}, \mathrm{n}}\right)$ are shown for the 3 different mean transmembrane pressure $\left(\Delta \mathrm{p}_{\mathrm{TM}, \mathrm{m}}\right)$ values.

\section{Calculation of the Wall Shear Stress}

The wall shear stress $\left(\tau_{\mathrm{w}}\right)$ was calculated from the pressure difference $\left(\Delta \mathrm{p}_{\mathrm{L}}\right)$ between inlet and outlet of the membrane according to equation [2], where $\mathrm{d}$ is membrane channel internal diameter (meters) and $\mathrm{L}$ is membrane length (meters):

$$
\tau_{\mathrm{w}}=\frac{\Delta \mathrm{p}_{\mathrm{L}} \cdot \mathrm{d}}{4 \cdot \mathrm{L}} .
$$

For comparison of the different membranes, the same pressure difference of $0.90 \times 10^{5} \mathrm{~Pa}$ was used in all experiments, resulting in slightly different values for $\tau_{\mathrm{w}}$. The mean value of $\tau_{\mathrm{w}}$ of the different filtrations was 108 $\pm 4 \mathrm{~Pa}$. Deviations of the $\tau_{\mathrm{w}}$ values were observed due to small variations of the membrane channel internal diameter.

\section{Calculation of Filtration Resistances}

The membrane resistance $R_{M}$ and total filtration resistance $\left(\mathbf{R}_{\text {tot }}\right)$ were calculated according to Darcy's law (eq. [3]) with the permeate viscosity $\eta_{\mathrm{p}}(\mathrm{Pa} \cdot \mathrm{s})$ and the permeate flux $J_{\mathrm{p}}\left(\mathrm{L} \cdot \mathrm{m}^{-2} \cdot \mathrm{h}^{-1}\right)$ :

$$
\mathrm{R}_{\mathrm{tot}}=\frac{\Delta \mathrm{p}_{\mathrm{TM}}}{\eta_{\mathrm{p}} \cdot \mathrm{J}_{\mathrm{p}}}
$$

A water viscosity of $504 \times 10^{-6} \mathrm{~Pa} \cdot \mathrm{s}\left(\vartheta=55^{\circ} \mathrm{C}\right)$ was used for the calculations. The MF permeate viscosity of $570 \times 10^{-6} \mathrm{~Pa} \cdot \mathrm{s}$ was measured using a capillary viscosimeter (model 537 10/1, Schott GmbH, Mainz, Germany) at $55^{\circ} \mathrm{C}$. The membrane resistance $\mathrm{R}_{\mathrm{M}}$ was determined by measuring the water flux $\mathrm{J}_{\mathrm{W}}$ for the 4 sections as a function of transmembrane pressure.

The fouling resistance $\left(\mathbf{R}_{\text {Foul }}\right)$ for the filtration milk was calculated by equation [4]:

$$
\mathrm{R}_{\text {Foul }}=\mathrm{R}_{\text {tot }}-\mathrm{R}_{\mathrm{M}} \text {. }
$$

In the fouling resistance $R_{\text {Foul }}$, the deposit layer formation, adsorption of particles on the membrane surface and in the membrane pores are included. Fouling resistance can be further differentiated in a pressuredependent part $\left(\mathbf{R}_{\text {Foul,pd }}\right)$ and a pressure-independent part $\left(\mathbf{R}_{\text {Foul,pi }}\right)$ to differentiate between pure adsorption and convective flow induced deposit formation. Further, reversible $\left(\mathbf{R}_{\text {Foul,rev }}\right)$ and irreversible $\left(\mathbf{R}_{\text {Foul,irr }}\right)$ fouling resistance can be assessed as a measure for the strength of binding between foulant and membrane. Thus, $\mathrm{R}_{\text {Foul,irr }}$ was defined by measuring the difference of the stationary water flux before and after filtration. The measured water flux after the filtration was dependent on the sum of the membrane resistance and the irreversible fouling resistance. The reversible fouling resistance was calculated by subtracting $R_{\text {Foul,irr }}$ from $R_{\text {Foul }}$. A method for differentiating the pressure-dependent and pressureindependent fouling will be introduced in the Results and Discussion section.

The hydraulic resistance $R_{M}$ could be determined by applying Hagen-Poiseuille law [5] with porosity $\varepsilon$, correction factor $\mu_{\mathrm{L}}$ (dimensionless), which describes the meandering of actual pores inside the membrane (typically 2.5 is used), the length $\mathrm{L}$ of the porous layer and the particle diameter $d_{p}$. Assuming that porosity and pore sizes are the same for the membranes studied, a linear relationship should exist between the increase of the selective layer and the increase in membrane re- 
sistance, which was the case for the membranes studied (data not shown):

$$
\mathrm{R}_{\mathrm{M}}=\frac{9}{4} \cdot \frac{(1-\varepsilon)^{2}}{\varepsilon^{3}} \cdot \frac{\mu_{\mathrm{L}} \mathrm{L}}{\mathrm{d}_{\mathrm{p}}^{2}}
$$

\section{Transmission of $\beta-L G$}

Protein concentrations of the 2 major whey proteins, $\beta$-LG and $\alpha$-LA, were determined by reversed-phase (RP)-HPLC using a method described by Beyer (1990) and Tolkach and Kulozik (2005). The ratio between these 2 whey proteins is about $80 \%(\beta-\mathrm{LG})$ to $20 \%(\alpha-$ LA). In previous studies, it was shown that the transmission of $\alpha$-LA was up to $10 \%$ higher (Le Berre and Daufin, 1996; Gésan-Guiziou et al., 1999), depending on the process conditions, which is in good agreement with our results. Because of its higher content and the better reproducibility in the RP-HPLC measurements, only $\beta-L G$ was taken as representative whey protein for the calculation of the protein transmission and the specific mass flux. The mean concentration $\left(\mathbf{c}_{\beta-\mathrm{LG}}\right.$, retentate $)$ in the retentate samples was $3.5 \pm 0.2 \mathrm{~g} / \mathrm{L}$. The $\beta-\mathrm{LG}$ transmission $\left(\mathbf{P}_{\beta-\mathrm{LG}}\right)$, also called sieving coefficient, was calculated according to equation [6] with the concentration of $\beta$-LG $\left(\mathbf{c}_{\beta-\mathrm{LG}}\right.$, permeate $)$ in the permeate.

$$
\mathrm{P}_{\beta-\mathrm{LG}}=\frac{\mathrm{c}_{\beta-\mathrm{LG}}, \text { permeate }}{\mathrm{c}_{\beta-\mathrm{LG}, \text { retentate }}} \times 100 \% .
$$

The transmission $(\mathrm{P})$ of molecules through a porous layer such as a membrane can be calculated by Ferry's law [7] with the pore size $r_{m}$ of the molecule to be filtered and the pore size $r$ of the fouled membrane

$$
P=1-\left[1-\left(1-\frac{r_{m}}{r}\right)^{2}\right]^{2}
$$

In case of a pore constriction due to fouling, the pore size of the fouled membrane can be determined by equation [8] as suggested by Zeman (1983), with the pore size $r_{0}$ of the clean membrane

$$
r=\left(\frac{\mathrm{R}_{\mathrm{M}}}{\mathrm{R}_{\mathrm{F}}}\right)^{0.25} \times r_{0} .
$$

The size of the $\beta$-LG molecule is about 3 to $4 \mathrm{~nm}$. Assuming unhindered $\beta$-LG permeation through a MF membrane with a pore size of $0.1 \mu \mathrm{m}$, no retention takes place and $c_{\beta-\mathrm{LG}}$, permeate $=\mathrm{c}_{\beta-\mathrm{LG}}$, retentate and, thus,
$\mathrm{P}_{\beta-\mathrm{LG}}=1$, or $100 \%$. By experience, we know that deposit formation of the casein fraction reduces the whey protein permeation to $\mathrm{P}_{\beta-\mathrm{LG}}<1$. The additional deposit layer on the membrane can be characterized by applying equation [7] and [8] to the filtration results of Piry et al. (2008). At a mean transmembrane pressure of $0.5 \times 10^{5} \mathrm{~Pa}\left(\tau_{\mathrm{w}}=115 \mathrm{~Pa}, \vartheta=55^{\circ} \mathrm{C} ; \mathrm{R}_{\mathrm{M}}=3.4 \times 10^{11}\right.$ $\left.\mathrm{m}^{-1}\right)$, they found a mean flux of $118 \mathrm{~L} \cdot \mathrm{h}^{-1} \cdot \mathrm{m}^{-2}\left(\mathrm{R}_{\text {tot }}\right.$ $=2.70 \times 10^{12} \mathrm{~m}^{-1}$ ) and a mean permeation of $\beta-\mathrm{LG}$ of $50 \%$. Considering that the fouling would be due to pore constriction, the pore diameter of the membrane would be reduced from 100 to $60 \mathrm{~nm}$ according to equation [8]. With this pore size, a permeation of $98 \%$ for $\beta-L G$ would be expected according to Ferry's law. For an average permeation of $50 \%$, a pore size for the fouled membrane of around $9 \mathrm{~nm}$ would be necessary. This would result in a filtration resistance of $5.2 \times 10^{15} \mathrm{~m}^{-1}$ and a flux of $0.06 \mathrm{~L} \cdot \mathrm{h}^{-1} \cdot \mathrm{m}^{-2}$. Because of the discrepancy between increase of resistance by pore constriction and permeation of $\beta$-LG, it can be concluded that the main fouling mechanism must be a thin additional deposit layer on the membrane, which reduces the permeation of $\beta-\mathrm{LG}$.

\section{Specific Mass Flux of $\beta-L G$}

The specific convective mass flow of $\beta-\mathrm{LG}\left(\dot{\mathrm{m}}_{\beta-\mathrm{LG}}\right)$ was calculated by multiplying the flux $\left(J_{\mathrm{p}}\right)$ with the concentration of $\beta-\mathrm{LG}$ in the permeate $\left(\mathrm{c}_{\beta-\mathrm{LG}}\right.$, permeate $)$ according to equation [9]:

$$
\dot{\mathrm{m}}_{\beta-\mathrm{LG}}=\mathrm{J}_{\mathrm{p}} \cdot \mathrm{c}_{\beta-\mathrm{LG}, \text { permeate }},
$$

where $\dot{\mathrm{m}}_{\beta-\mathrm{LG}}$ is the decisive criterion when whey proteins are to be depleted from milk by means of a multistage diafiltration process. The higher the value for $\dot{\mathrm{m}}_{\beta-\mathrm{LG}}$, the faster the diafiltration.

\section{RESULTS AND DISCUSSION}

\section{Effect of Membrane Length Dependency on Flux and Fouling Behavior}

Ideally, a linear relationship between $\mathrm{J}_{\mathrm{p}}$ and $\Delta \mathrm{p}_{\mathrm{TM}}$ is obtained. However, this is only the case until, at higher values of $\Delta \mathrm{p}_{\mathrm{TM}}$, deposit layer formation starts at a certain critical point, $J_{\text {crit }}$ and $\Delta \mathrm{p}_{\mathrm{TM}, \text { crit }}$. Beyond this point, deposit layer formation increasingly influences permeation, resulting in an underproportional increase of $\mathrm{J}_{\mathrm{p}}$ when $\Delta \mathrm{p}_{\mathrm{TM}}$ is further increased. Finally, the limiting or pressure-independent flux $\left(\mathbf{J}_{\text {lim }}\right)$ is reached and the filtration over the whole membrane is dominated by a deposit layer (Field et al., 1995). It was shown that 
a)

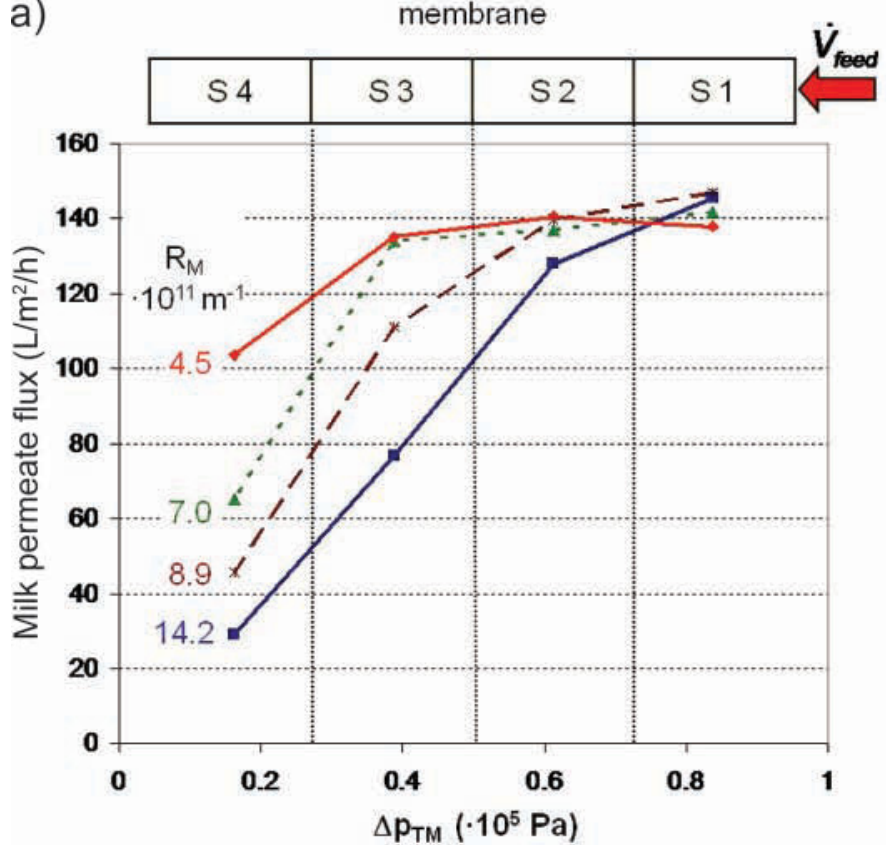

b)

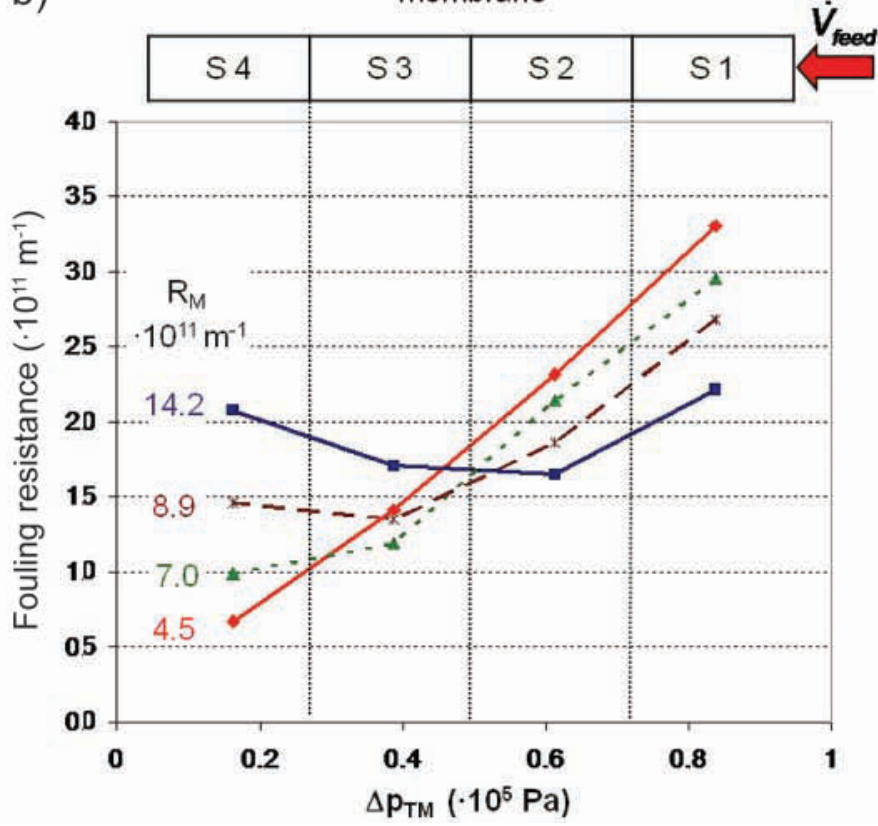

Figure 2. Skim milk flux values after $90 \mathrm{~min}$ (a) and resistances for the filtration of skim milk (b) along the 4 membrane sections, S1 to S4 $\left[\right.$ mean transmembrane pressure $\left(\Delta \mathrm{p}_{\mathrm{TM}, \mathrm{m}}\right)=0.5 \times 10^{5} \mathrm{~Pa}$; temperature $\vartheta=55^{\circ} \mathrm{C}$; wall shear stress $\tau_{\mathrm{w}}=108 \mathrm{~Pa}$, length $\left.=1.20 \mathrm{~m}\right] . \mathrm{R}_{\mathrm{M}}=\mathrm{mem}-$ brane resistance. Color version available in the online PDF.

milk microfiltration with similar process conditions as used in this study is limited to permeate flux values $\left(\mathrm{J}_{\mathrm{lim}}\right)$ between 125 and $147 \mathrm{~L} \cdot \mathrm{h}^{-1} \cdot \mathrm{m}^{-2}$ (Piry et al., 2008). The question whether particles will be deposited on the membrane surface depends on the particle size distribution (Altmann and Ripperger, 1997; Ripperger and Grein, 2007) and on the local filtration conditions (Piry et al., 2008).

In Figure 2a, the permeate flux of milk is depicted as a function of local $\Delta \mathrm{p}_{\mathrm{TM}}$ for the 4 sections (S1 to $\mathrm{S} 4)$. The $\Delta \mathrm{p}_{\mathrm{TM}}$ decreased from membrane inlet to membrane outlet and therefore $\Delta \mathrm{p}_{\mathrm{TM}}$ has to be regarded as a length-dependent variable. For all 4 membranes with different permeation resistances, the permeate flux is similar in the first section with values between 138 and $147 \mathrm{~L} \cdot \mathrm{h}^{-1} \cdot \mathrm{m}^{-2}$. This means that in $\mathrm{S} 1$, the flux is dominated by the deposited protein material on the membrane, meaning that the flux has reached $\mathrm{J}_{\mathrm{lim}}$. Higher membrane resistances lead to higher $\Delta \mathrm{p}_{\mathrm{TM}, \text {,rit }}$. Therefore, for the membrane with the highest membrane resistance, the milk permeate flux decreases from inlet to outlet (S1 to S4). From S2 to S4, the expected linear relationship between $J$ and $\Delta \mathrm{p}_{\mathrm{TM}}$ indicates that no significant deposit layer formation takes place. For lower $R_{M}$ values, larger parts of the membrane are dominated by a deposit layer and therefore the flux curves start to deviate from the linear shape at lower $\Delta \mathrm{p}_{\mathrm{TM}}$ values in the sections closer to the membrane outlet.
Except for the membrane with lowest $\mathrm{R}_{\mathrm{M}}, \Delta \mathrm{p}_{\mathrm{TM}}$ was lower than $\Delta \mathrm{p}_{\mathrm{TM}, \text { crit }}$ in $\mathrm{S} 4$. When higher membrane resistances are used, the linear relationship between flux and $\Delta \mathrm{p}_{\text {TM }}$ applies for $\mathrm{S} 4$ to $\mathrm{S} 3$ and $\mathrm{S} 4$ to $\mathrm{S} 2$, respectively, and $\Delta \mathrm{p}_{\mathrm{TM} \text {,crit }}$ shifts to higher values and moves toward the membrane inlet.

The observed distribution of flux across a membrane influences the length dependency of the fouling resistance. In Figure $2 \mathrm{~b}$, the $\mathrm{R}_{\text {Foul }}$ of the filtrations is depicted. An almost inverse picture can be seen compared with Figure 2a. The value of $\mathrm{R}_{\text {Foul }}$ decreases almost linearly from inlet to outlet for the membrane with lowest $R_{M}$, which is mainly dominated by a deposit layer. In this case, the difference in the deposit layer resistance between membrane inlet and outlet is the largest, whereas for the highest $R_{M}$ value, $R_{\text {Foul }}$ is relatively stable along the membrane and varies only between 1.6 and $2.2 \times 10^{12} \mathrm{~m}^{-1}$.

In the first section, the same $J_{P}$ values and equal $R_{\text {tot }}$ are obtained for all studied membrane resistances. According to equation [4], $R_{\text {Foul }}$ is the difference between $R_{\text {tot }}$ and $R_{M}$. In case of a higher $R_{M}$, comparably lower values for $\mathrm{R}_{\text {Foul }}$ are observed. In $\mathrm{S} 1$, the combination of high transmembrane pressure and low membrane resistance leads to high initial flux values at the beginning of filtration upon changing over from water to milk. This induces a strong convective flow and forces material (mainly casein micelles) toward the membrane 
a)

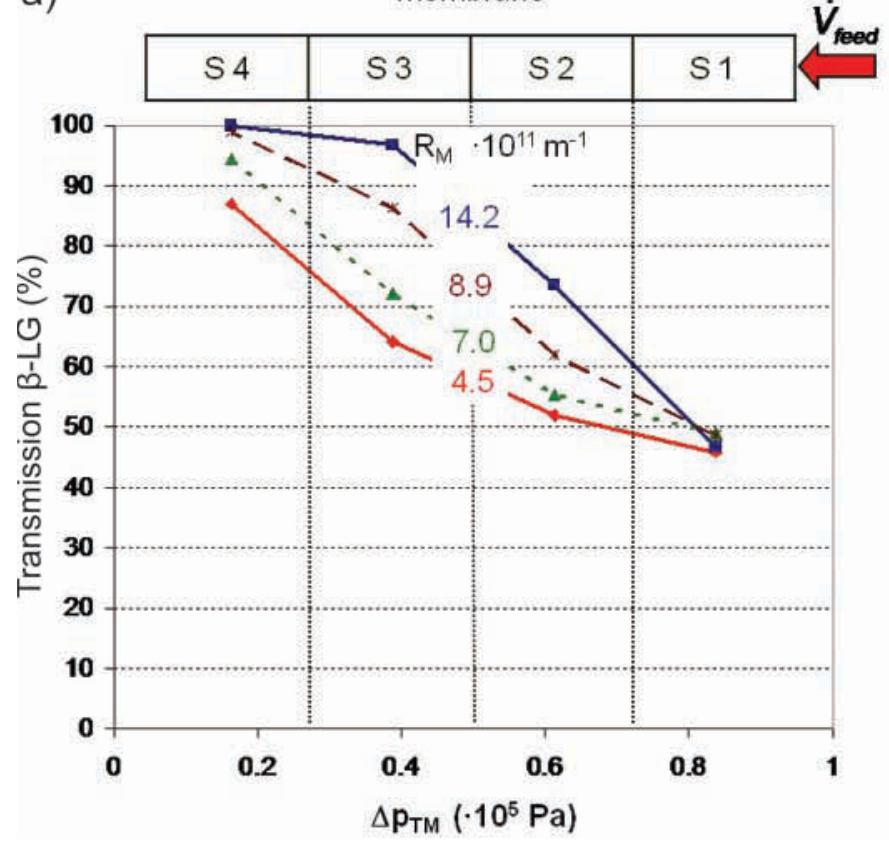

b)

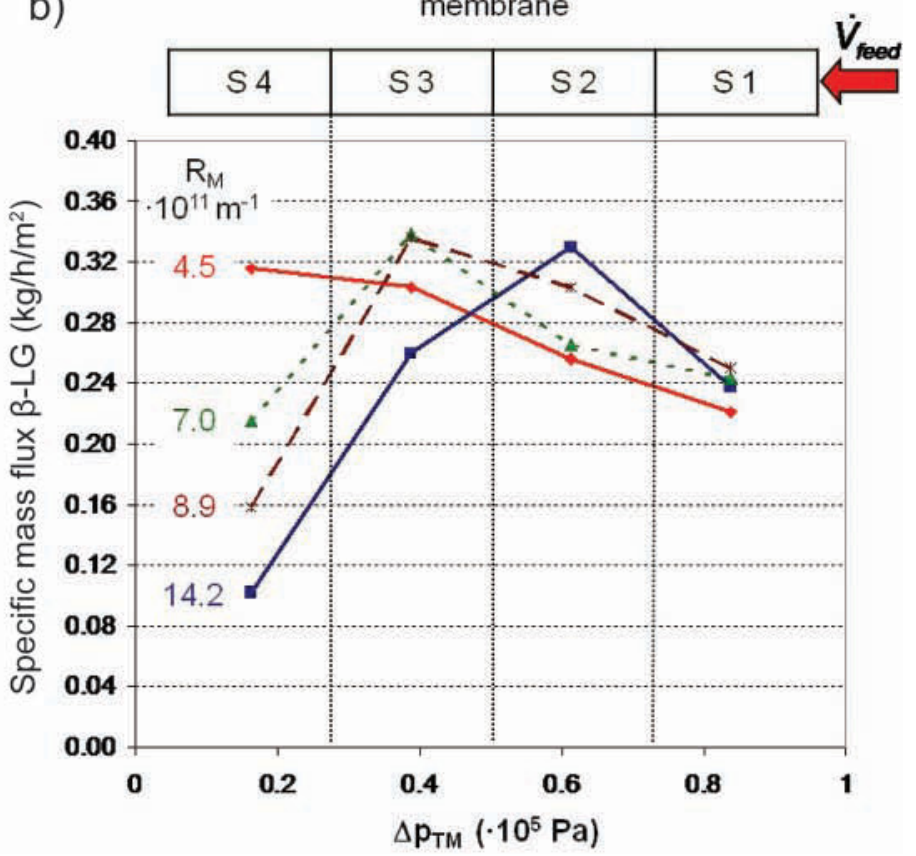

Figure 3. Permeation (a) and specific mass flux of $\beta$-LG (b) along the 4 membrane sections, S1 to S4 [mean transmembrane pressure $\left(\Delta \mathrm{p}_{\mathrm{TM}, \mathrm{m}}\right)=0.5 \times 10^{5} \mathrm{~Pa}$; temperature $\vartheta=55^{\circ} \mathrm{C}$; wall shear stress $\tau_{\mathrm{w}}=108 \mathrm{~Pa}$, length $\left.\mathrm{L}=1.20 \mathrm{~m}\right]$. $\mathrm{R}_{\mathrm{M}}=$ membrane resistance. Color version available in the online PDF.

surface, where it is retained and deposited (Piry et al., 2008). By increasing the membrane resistance, the initial convective flow, and consequently the fouling at the membrane inlet, can be reduced. It is obvious from Figure $2 \mathrm{~b}$ that $\mathrm{R}_{\text {Foul }}$ is not decreasing to values near zero, even for those sections that are operated below $\mathrm{J}_{\text {crit }}$. Also, under membrane-controlled filtration conditions, boundary layer effects such as adsorption of proteins cause an increase of the filtration resistance compared with water, as was observed by Carić et al. (2000). According to Bacchin et al. (2006), for this filtration behavior, $J_{\text {crit }}$ is the transition between fouling caused by boundary layer effects such as adsorption, which are independent from the solvent flow toward the membrane, and fouling caused additionally by convective mass deposition.

\section{Length Dependency of Whey Protein Transmission and Specific Mass Flux}

The observed distribution of fouling resistance has a strong effect on the permeation of $\beta-\mathrm{LG}$, as shown in Figure 3 , where transmission of $\beta-\mathrm{LG}$ and specific mass flux of $\beta$-LG are depicted as a function of $\Delta \mathrm{p}_{\mathrm{TM}}$ section by section.

For the 4 membranes investigated, transmission $\mathrm{P}_{\beta-\mathrm{LG}}$ varied from 46 to $49 \%$ in $\mathrm{S} 1$ and increases toward $\mathrm{S} 4$ to values of 87 to $99 \%$ depending on the membrane resistance (Figure 3a). It can be seen that the whey protein transmission increases with higher membrane resistance and lower transmembrane pressure. For the highest membrane resistance, an unhindered transmission of $\beta$-LG was observed in S3 and S4, demonstrating that fouling effects (such as adsorption) in these sections do not affect protein transmission. Although the permeate flux increased linearly from S3 to S2 for the highest $\mathrm{R}_{\mathrm{M}}, \mathrm{P}_{\beta-\mathrm{LG}}$ decreased to $74 \%$ in $\mathrm{S} 2$, indicating an additional fouling effect. Because the retention of whey proteins is mainly attributed to deposit layer formation, we conclude that the assessment of $\beta$-LG transmission allows detection of deposit layer formation at the first stages in a very sensitive way.

The specific mass flux of $\beta-\mathrm{LG}$ is depicted in Figure $3 \mathrm{~b}$. At the lowest $R_{M}$, the highest values are reached in $\mathrm{S} 4$. For higher $\mathrm{R}_{\mathrm{M}}$, this local maximum shifts toward the membrane inlet to the second and the third sections, respectively, with values between 0.320 and 0.340 $\mathrm{kg} \cdot \mathrm{m}^{-2} \cdot \mathrm{h}^{-1}$.

For the different membrane resistances studied, the highest protein mass flux values were found in those sections where both a high transmission of $\beta$-LG and a high permeate flux were obtained. The maxima found for the $\beta$-LG mass flux corresponded to similar initial water flux values between 320 and $430 \mathrm{~L} \cdot \mathrm{h}^{-1} \cdot \mathrm{m}^{-2}$. 


\section{Dependency of Milk Flux on Water Flux}

Based on this observation, we assessed the relationship between initial water flux and milk permeate flux. Because membrane manufacturers and users tend to produce and apply, respectively, membranes with preferably high water fluxes, it can be expected that the effect of a rapid deposit formation immediately after switching from water to milk at production start could be avoided by selecting membranes with a higher permeation resistance. To support this hypothesis, clean membrane initial water flux values were compared with the flux obtained for the MF for milk.

In Figure 4, the milk permeate flux values of all membrane sections (mean $\Delta \mathrm{p}_{\mathrm{TM}}=0.50 \times 10^{5} \mathrm{~Pa}$ ) are depicted relative to their respective water fluxes. The permeate flux for milk increases linearly up to a value of $140 \mathrm{~L} \cdot \mathrm{h}^{-1} \cdot \mathrm{m}^{-2}$ until a water flux value of around $400 \mathrm{~L} \cdot \mathrm{h}^{-1} \cdot \mathrm{m}^{-2}$ is reached. Beyond this point, the milk flux levels off sharply, not exceeding flux values of 140 $\mathrm{L} \cdot \mathrm{h}^{-1} \cdot \mathrm{m}^{-2}$. We conclude that the filtration is membrane controlled if a critical initial water flux of $400 \mathrm{~L} \cdot \mathrm{h}^{-1} \cdot \mathrm{m}^{-2}$ is not exceeded locally, whereas beyond this point casein micelles are deposited on the membrane and milk flux is unavoidably controlled by a deposit layer. The 4 membranes studied show a similar behavior with respect to milk flux as a function of initial water flux. Similar values of around $140 \mathrm{~L} \cdot \mathrm{h}^{-1} \cdot \mathrm{m}^{-2}$ for the limiting flux were found. For all 4 membranes, the deposit layer formation starts when a certain convective flow toward the membrane is exceeded. For the membranes studied, it was possible to predict which area of the membrane was controlled by a deposit layer by considering the local water flux distribution. Because the water flux decreased linearly from inlet to outlet, it was only necessary to calculate at which local position along the membrane the critical water flux value of $400 \mathrm{~L} \cdot \mathrm{h}^{-1} \cdot \mathrm{m}^{-2}$ was reached.

When the corresponding transmembrane pressures were calculated for this critical water flux value of 400 $\mathrm{L} \cdot \mathrm{h}^{-1} \cdot \mathrm{m}^{-2}$, by applying Darcy's law, a $\Delta \mathrm{p}_{\mathrm{TM}, \text { crit }}$ of 0.25 $\times 10^{5} \mathrm{~Pa}$ was found for the membrane with lowest resistance, whereas a $\Delta \mathrm{p}_{\mathrm{TM}, \text { crit }}$ of $0.80 \times 10^{5} \mathrm{~Pa}$ was determined for the highest membrane resistance. These critical pressure values are reached in $\mathrm{S} 4$ for the lowest $R_{M}$ and in $S 1$ for the highest $R_{M}$, as can be seen in Figure 2a.

Based on the definition of critical flux given the first section of the Results and Discussion, it must be emphasized that for conventional crossflow filtration the deposit layer formation starts at that particular local position of the membrane, where the convective flow exceeds a certain critical value and particles are deposited on the membrane surface. Therefore, $J_{\text {crit }}$ depends not only on the particle size distribution of the fluid to be filtered but also on the variability of initial flux along the membrane.

\section{Differentiation Between Pressure-Dependent and Pressure-Independent Fouling}

Although the viscosity for milk permeate at $55^{\circ} \mathrm{C}$ was only $13 \%$ higher compared with pure water, a large difference was observed between milk permeate flux and water flux in the membrane controlled area of Figure 4. This means that $R_{\text {tot }}$ for the filtration of milk is also increased in the membrane-controlled part compared with water. Therefore, it is worth studying the ratio between $R_{\text {tot }}$ and $R_{M}$ as a function of water flux.

In Figure 5 it can be seen that below a water flux of $400 \mathrm{~L} \cdot \mathrm{h}^{-1} \cdot \mathrm{m}^{-2}$, the ratio of resistances is independent from the water flux with a value of 2.33 , whereas above $400 \mathrm{~L} \cdot \mathrm{h}^{-1} \cdot \mathrm{m}^{-2}$, the ratio increased linearly with a slope of $6.3 \times 10^{-3} \mathrm{~L} \cdot \mathrm{h}^{-1} \cdot \mathrm{m}^{-2}$. Below this water flux, fouling phenomena such as adsorption may take place, reducing either the pore size or the porosity of the membrane. Applying equation [5] and only considering that the fouling would lead to a pore constriction, a factor of 2.3 higher resistance means a reduction

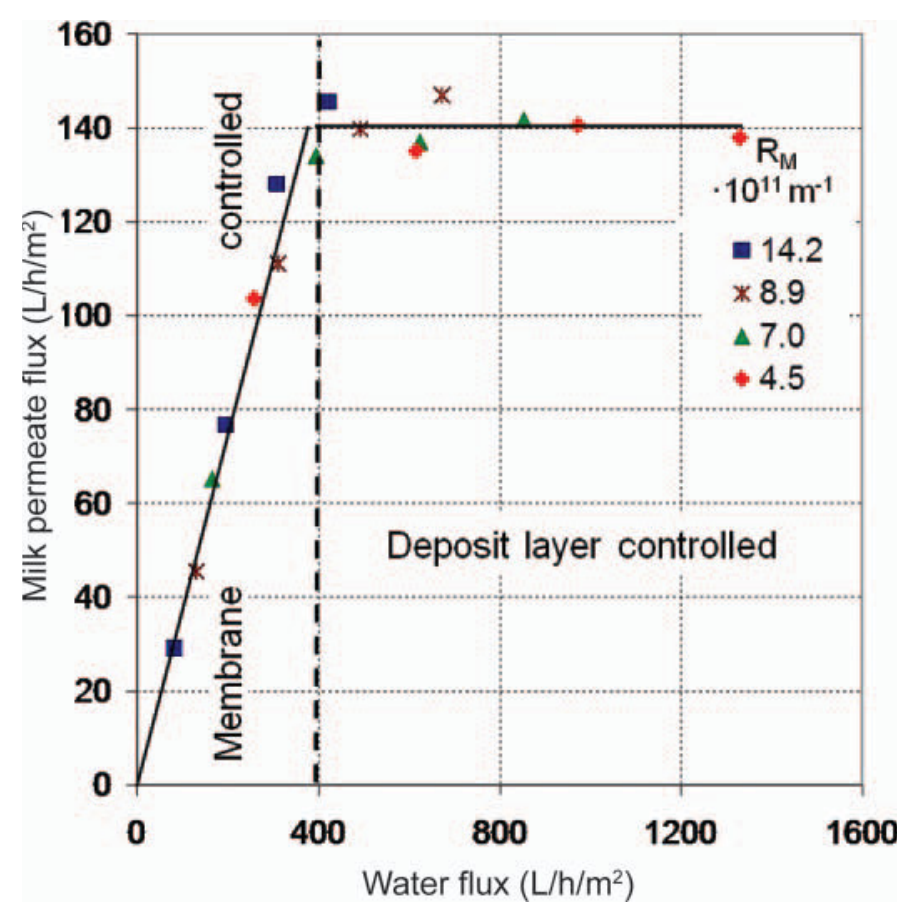

Figure 4. Skim milk flux as a function of the initial water flux of the clean membrane (wall shear stress $\tau_{\mathrm{w}}=108 \mathrm{~Pa}$, temperature $\vartheta$ $\left.=55^{\circ} \mathrm{C}\right) \cdot \mathrm{R}_{\mathrm{M}}=$ membrane resistance. Color version available in the online PDF. 


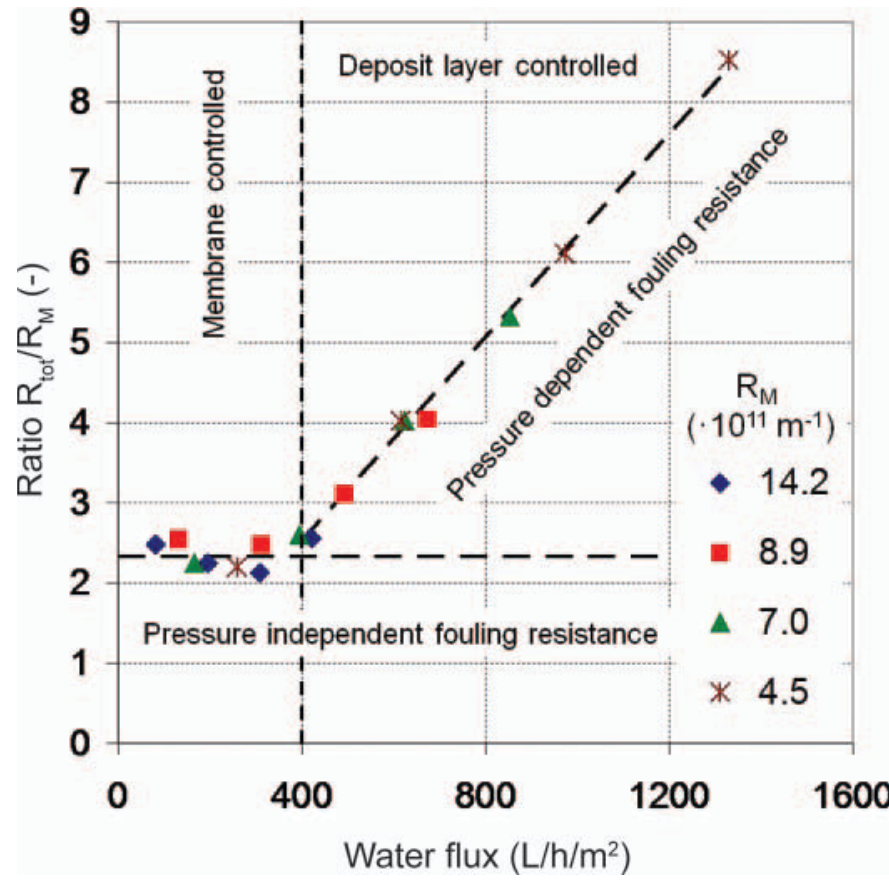

Figure 5. Fouling resistance as a function of the initial water flux of the clean membrane (wall shear stress $\tau_{\mathrm{w}}=108 \mathrm{~Pa}$, temperature $\vartheta$ $\left.=55^{\circ} \mathrm{C}\right) . \mathrm{R}_{\mathrm{M}}=$ membrane resistance; $\mathrm{R}_{\text {tot }}=$ total filtration resistance. Color version available in the online PDF.

of the membrane's nominal pore size of $33 \%$ (to 66 $\mathrm{nm})$. At this pore size, an unhindered permeation of $\beta-\mathrm{LG}$ is still possible, considering Ferry's law (equation [7]), which was also observed in this study. Because the membrane resistance was varied by the height of the selective layer, internal fouling processes such as adsorption would lead to similar factors for the increase of total filtration resistance and therefore to higher pressure-independent fouling resistance for membranes with higher membrane resistance.

Above a water flux of $400 \mathrm{~L} \cdot \mathrm{h}^{-1} \cdot \mathrm{m}^{-2}$, an additional resistance due to deposit layer formation led to an increased ratio of $R_{\text {tot }}$ to $R_{\mathrm{M}}$. In that area, this ratio of resistance is dependent on the water flux. Interestingly, all membranes showed the same behavior in the deposit layer-controlled area. When a deposit layer is formed, the permeate flux through the deposit is limited to $\mathrm{J}_{\lim }$ and therefore its compaction is a function of the transmembrane pressure. The increase of the fouling resistance itself in the deposit layer-controlled area is therefore dependent on the transmembrane pressure. Applying Darcy's law, the pressure dependency can be calculated to be $4.5 \times 10^{7} \mathrm{~m}^{-1} \mathrm{~Pa}^{-1}$. This is in agreement with the results depicted in Figure 1b, where a similar increase of fouling resistance was observed for the deposit layer-controlled membrane parts.
With the results shown in Figure 5, it is possible to empirically calculate the pressure-dependent and pressure-independent fouling. For the $\mathrm{R}_{\text {Foul,pi }}$, equation [10] can be applied:

$$
\mathrm{R}_{\text {Foul }, \text { pi }}=1.33 \cdot \mathrm{R}_{\mathrm{M}} \text {. }
$$

The factor of 1.33 results from subtracting $R_{M}$ from the ratio of $R_{\text {tot }}: R_{M}$ (which is 2.33).

For $\mathrm{R}_{\text {Foul,pd }}$ due to deposit layer formation above the critical water flux of $400 \mathrm{~L} \cdot \mathrm{h}^{-1} \cdot \mathrm{m}^{-2}$ equation [11] can be used:

$$
\mathrm{R}_{\text {Foul,pd }}=6.34 \times 10^{-3} \mathrm{~J}_{\mathrm{W}} \cdot \mathrm{R}_{\mathrm{M}}-\mathrm{R}_{\text {Foul,pi }} \text {. }
$$

The factor of $6.34 \times 10^{-3}$ is the slope of the increase of $\mathrm{R}_{\text {tot }}: \mathrm{R}_{\mathrm{M}}$; it has the unit of $\mathrm{L}^{-1} \cdot \mathrm{m}^{2} \cdot \mathrm{h}$.

\section{Influence of $\Delta p_{T M, m}$ and $R_{M}$ on Permeate Flux and Permeation of $\beta-L G$}

From these findings, we conclude that it is of great interest to know at which combination of $\mathrm{R}_{\mathrm{M}}$ and $\Delta \mathrm{p}_{\mathrm{TM}}$ the highest permeate flux and mass permeation values for $\beta-L G$ can be achieved across the whole membrane with a length of $1.2 \mathrm{~m}$. To assess this relationship, the membrane was considered as one piece, without further differentiating between the membrane sections.

The permeate flux of skim milk as a function of $R_{M}$ is depicted for 3 different mean $\Delta \mathrm{p}_{\mathrm{TM}}$ values (Figure 6). At mean $\Delta \mathrm{p}_{\mathrm{TM}, \mathrm{m}}$ of $0.50 \times 10^{5} \mathrm{~Pa}$, the flux difference between the lowest and the highest $R_{M}$ was 32 $\mathrm{L} \cdot \mathrm{h}^{-1} \cdot \mathrm{m}^{-2}$. When increasing $\Delta \mathrm{p}_{\mathrm{TM}, \mathrm{m}}$, the flux difference was less pronounced.

For the lowest $R_{M}$, large parts of the membrane were controlled through a deposit layer already at $\Delta \mathrm{p}_{\mathrm{TM}, \mathrm{m}}$ of $0.50 \times 10^{5} \mathrm{~Pa}$. A stronger increase of permeate flux at higher $\Delta \mathrm{p}_{\mathrm{TM}, \mathrm{m}}$ was observed for higher membrane resistances, because only those membrane areas that are not controlled by a deposit layer can contribute to a further flux increase.

Membranes with higher intrinsic resistances showed an increased $\beta-\mathrm{LG}$ transmission. In Figure 7, the transmission and specific mass flux of $\beta$-LG are depicted as a function of $\mathrm{R}_{\mathrm{M}}$. The transmission of $\beta$-LG was highest for the membrane with the highest $R_{M}$ value, with only a small decrease at higher $\Delta \mathrm{p}_{\mathrm{TM}}$.

Consistent with this result, at $\Delta \mathrm{p}_{\mathrm{TM}, \mathrm{m}}$ of $0.50 \times 10^{5}$ $\mathrm{Pa}$, the highest specific mass flux of $\beta$-LG was found for the filtration with lowest $R_{\mathrm{M}}$, whereas at $\Delta \mathrm{p}_{\mathrm{TM}, \mathrm{m}}$ of 0.65 $\times 10^{5} \mathrm{~Pa}$, similar values for all 4 membrane resistances can be observed. The largest specific mass flux of $\beta$-LG 


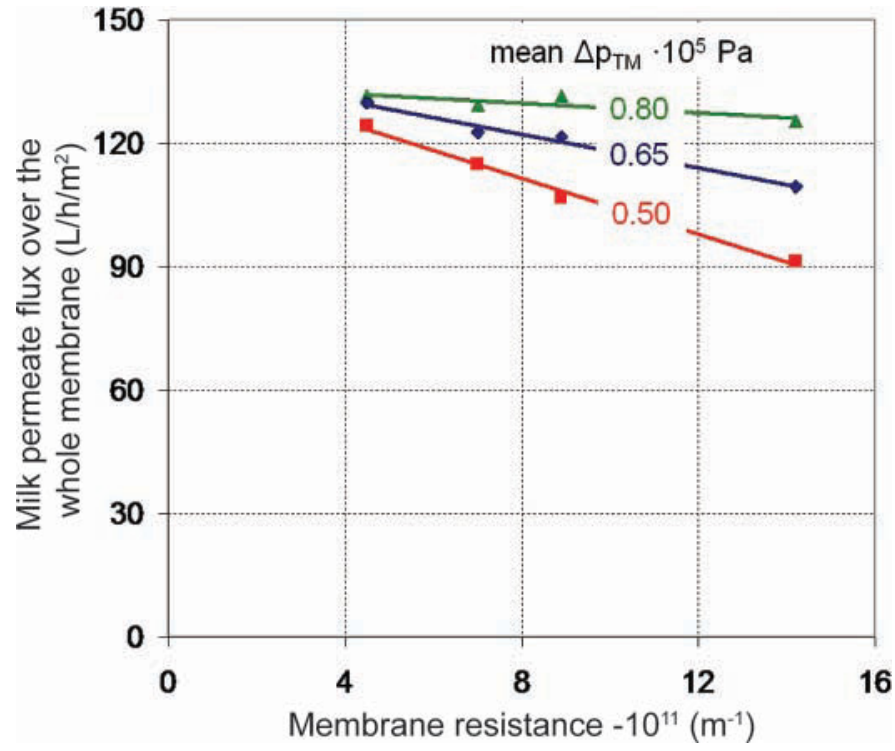

Figure 6. Skim milk flux values as a function of the membrane resistance for 3 membranes with different transmembrane pressures $\left(\Delta \mathrm{p}_{\mathrm{TM}}\right.$; mean values over the whole membrane; temperature $\vartheta=55^{\circ} \mathrm{C}$; wall shear stress $\tau_{\mathrm{w}}=108 \mathrm{~Pa}$, length $\mathrm{L}=1.20 \mathrm{~m}$ ). Color version available in the online PDF.

was found for the combination of a $\Delta \mathrm{p}_{\mathrm{TM}, \mathrm{m}}$ of $0.80 \times$ $10^{5} \mathrm{~Pa}$ and the highest $\mathrm{R}_{\mathrm{M}}$.

\section{Distribution of Reversible and Irreversible Fouling Resistance of Membranes with Different Membrane Resistances}

The intensity of fouling varies along the flow path of a tubular membrane, as demonstrated above. Therefore, we can assume that the removal of adsorbed and deposited material varies as a function of membrane permeation resistance. A differentiation between reversible and irreversible fouling can help to gain deeper insights into such fouling phenomena. Although reversible fouling can be removed by flushing the membrane, irreversible fouling is affected by the strongly bound deposit layer, adsorbed matter, blocked pores, and interactions between membrane and components in contact with the membrane, which cannot be eliminated by simply rinsing the membrane (Nakanishi and Kessler, 1985; Kulozik and Kessler, 1988).

In Figure 8, reversible and irreversible fouling is shown as a function of membrane length at the mean transmembrane pressure of $0.80 \times 10^{5} \mathrm{~Pa}$. At this pressure, similar flux values over the whole membrane were observed for all 4 membranes, as depicted in Figure 6. Consequently, the total filtration resistance was similar for the 4 membranes. However, the distribution of reversible fouling is quite different between these membranes. As shown in Figure 8a, reversible fouling resistance decreased linearly for the 2 membranes with lower membrane resistances, with similar slope from the inlet (S1) to the outlet (S4). These 2 membranes were almost completely deposit layer-controlled under these conditions. The membrane with the lowest $R_{M}$ had the highest reversible fouling, whereas the membrane with highest intrinsic resistance had the lowest reversible fouling values. Interestingly, the 2 membranes with higher resistance showed a minimum for reversible fouling at S3, where the critical flux was reached for these 2 membranes. As discussed above, fouling effects also appear below the critical flux and some of this fouling can be removed by flushing the membrane. From these results, we conclude that reversible fouling is mainly related to the formation of a deposit layer because it is reduced with increasing membrane resistance and shows in the deposit layer controlled area of the membrane a strong dependency on transmembrane pressure. With values of 3.1 to $4.4 \times 10^{7} \mathrm{~m}^{-1} \mathrm{~Pa}^{-1}$, the increase of reversible fouling resistance as a function of transmembrane pressure is lower as the increase of pressure-dependent fouling resistance calculated by equation [11] $\left(4.5 \times 10^{7} \mathrm{~Pa}\right)$. This means, therefore, that some pressure-dependent fouling is irreversible.

Compared with reversible fouling resistance, the irreversible fouling resistance depicted in Figure 8b shows no such strong dependency on transmembrane pressure. At first glance, it may not be expected that the irreversible fouling resistance would be lower for membranes with lower intrinsic resistance. However, 2

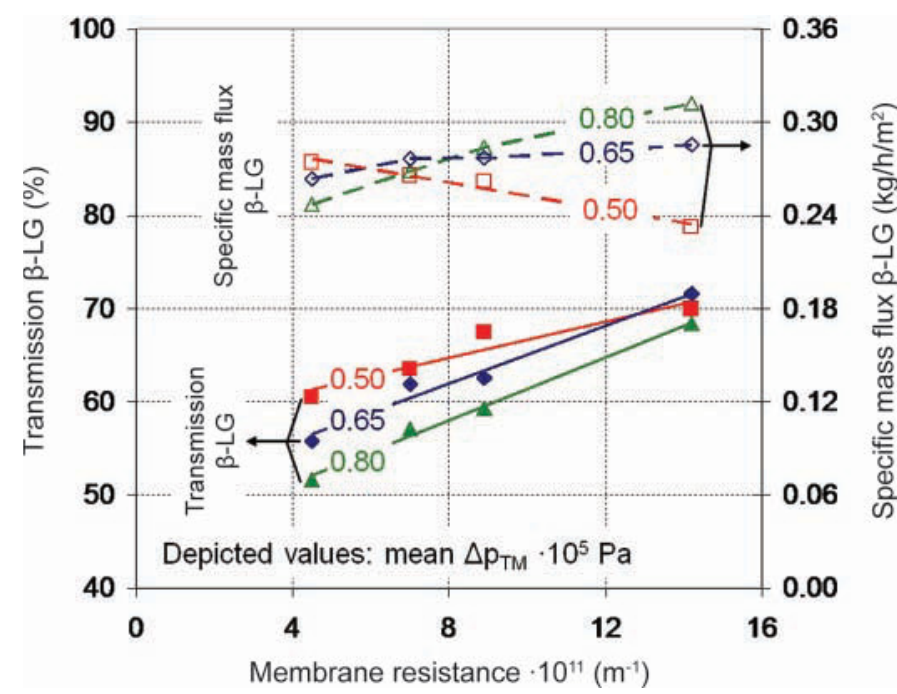

Figure 7. Permeation of $\beta-\mathrm{LG}$ and specific mass flux for $\beta-\mathrm{LG}$ as a function of the membrane resistance at 3 different transmembrane pressures $\left(\Delta \mathrm{p}_{\mathrm{TM}}\right.$; mean values over the whole membrane; temperature $\vartheta=55^{\circ} \mathrm{C}$; wall shear stress $\tau_{\mathrm{w}}=108 \mathrm{~Pa}$; length $\mathrm{L}=1.20 \mathrm{~m}$ ). Color version available in the online $\mathrm{PDF}$. 
a)
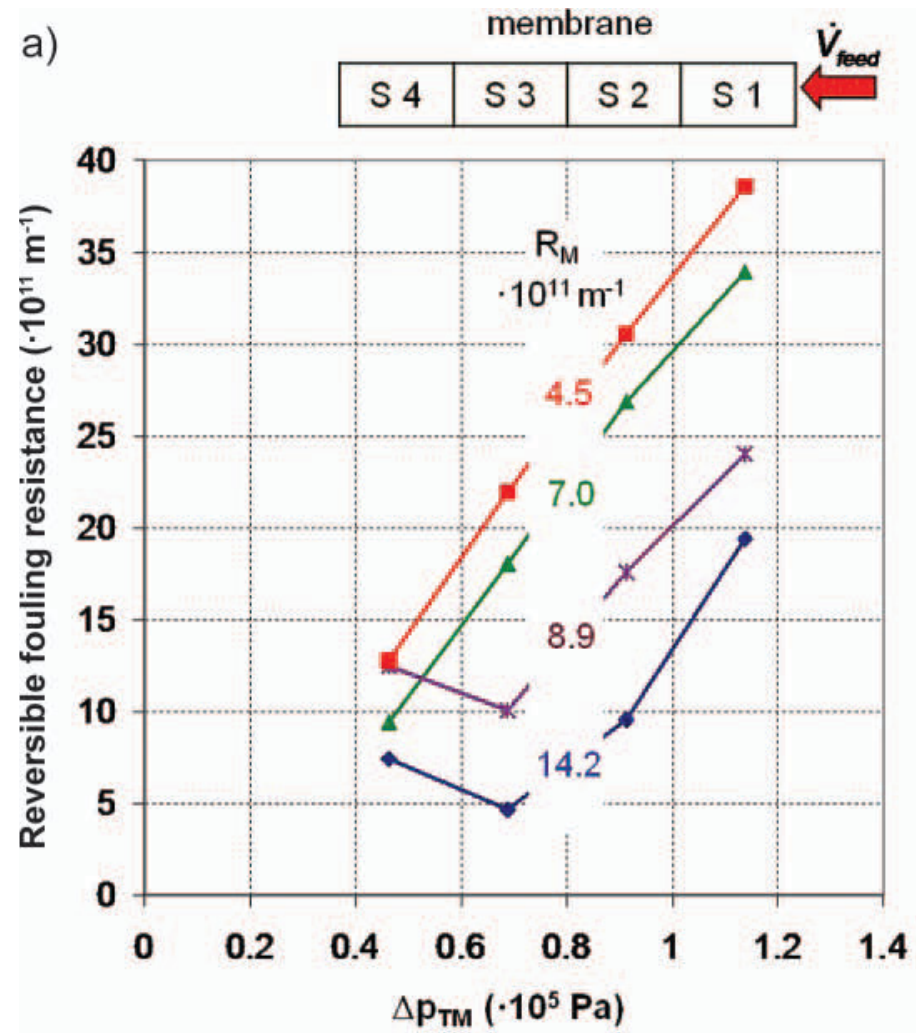

b)
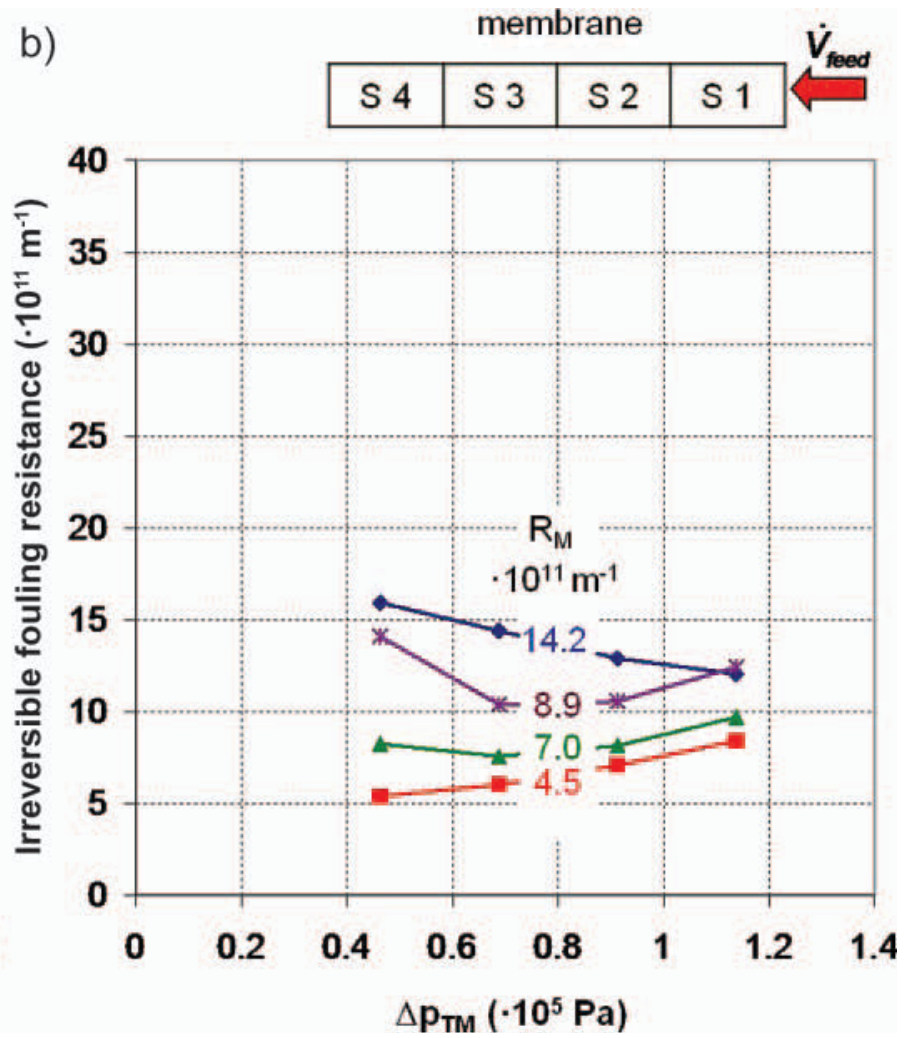

Figure 8. Reversible (a) and irreversible (b) fouling along the membranes as a function of transmembrane pressure [mean transmembrane pressure $\left(\Delta \mathrm{p}_{\mathrm{TM}, \mathrm{m}}\right)=0.8 \times 10^{5} \mathrm{~Pa}$; temperature $\vartheta=55^{\circ} \mathrm{C}$; wall shear stress $\tau_{\mathrm{w}}=108 \mathrm{~Pa}$, length $\left.\mathrm{L}=1.20 \mathrm{~m}\right]$. $\mathrm{R}_{\mathrm{M}}=$ membrane resistance. Color version available in the online $\mathrm{PDF}$.

mechanisms affect irreversible fouling. Below the critical flux, where deposit layer formation does not play a major role, adsorption and other fouling effects on the membrane surface and in the membrane pores are mainly responsible for irreversible fouling. The membrane's selective layer thickness is larger at higher $R_{M}$, meaning that a larger surface is available for interfacial interactions between product components and the membrane. Above the critical flux, the more compact and compressed deposit layer structure is responsible for the increase in irreversible fouling. Similar observations were made by Jimenez-Lopez et al. (2008). They found an especially strong irreversible fouling for UF permeate compared with skim milk and concluded that the deposit layer could also serve as a protective layer for the membrane. Because of these two mechanisms, the membranes with the lowest and the highest resistance, respectively, show completely different behaviors. For the membrane with the lowest resistance, which is mainly dominated by a deposit layer, an increase in irreversible fouling resistance occurs with initial water flux because of the more compact deposit layer structure. For the membrane with the highest resistance, which was barely affected by deposit layer formation,
$\mathrm{R}_{\text {Foul,irr }}$ decreases with higher transmembrane pressures. The other 2 membranes had a minimum for irreversible fouling in section S3.

In Table 2, irreversible fouling is compared with the pressure-independent fouling as mean values across the whole membrane. Irreversible fouling can be interpreted as fouling that cannot be removed by rinsing the membrane with water, whereas pressure-independent fouling is a measure of fouling effects (mainly adsorption) below the critical flux. The ratio of these measures will give indications about the reversibility of the pressure-independent fouling and about the increase of irreversible fouling due to deposit layer formation. For the membrane with the highest resistance, irreversible fouling was only $69 \%$ of pressure-independent fouling, meaning that some of the substances causing pressure-independent fouling are washed away. For the 2 medium membrane resistances, $\mathrm{R}_{\mathrm{M}}=8.9 \times 10^{11}$ $\mathrm{m}^{-1}$ and $\mathrm{R}_{\mathrm{M}}=7.0 \times 10^{11} \mathrm{~m}^{-1}$, irreversible fouling and pressure independent fouling were quite similar. The higher values for the ratio of irreversible to pressureindependent fouling were due to the stronger deposit layer formation for these 2 membranes. For the lowest membrane resistance, $\mathrm{R}_{\text {Foul,irr }}$ was about $20 \%$ higher 
Table 2. Comparison between irreversible fouling $\left(\mathrm{R}_{\text {Foul,irr }}\right)$ and pressure-independent fouling $\left(\mathrm{R}_{\text {Foul, pi }}\right)$ as mean values over the whole membrane [mean transmembrane pressure $\left(\Delta \mathrm{p}_{\mathrm{TM}, \mathrm{m}}\right)=0.8 \times 10^{5} \mathrm{~Pa}$; temperature $=$ $55^{\circ} \mathrm{C}$; wall shear stress $\left.=108 \mathrm{~Pa}\right]$

\begin{tabular}{|c|c|c|c|}
\hline $\begin{array}{l}\mathrm{R}_{\mathrm{M}}^{1} \\
\left(\times 10^{11} \mathrm{~m}^{-1}\right)\end{array}$ & $\mathrm{R}_{\text {Foul,irr }}\left(\times 10^{11} \mathrm{~m}^{-1}\right)$ & $\mathrm{R}_{\mathrm{Foul}, \mathrm{pi}}\left(\times 10^{11} \mathrm{~m}^{-1}\right)$ & $\begin{array}{c}\text { Ratio } \\
\mathrm{R}_{\text {Foul,irr }} / \mathrm{R}_{\text {Foul,pi }}(\%)\end{array}$ \\
\hline 4.5 & 13.01 & 18.89 & 69 \\
\hline 7.0 & 11.54 & 11.84 & 98 \\
\hline 8.9 & 8.61 & 9.31 & 92 \\
\hline 14.2 & 7.13 & 5.99 & 119 \\
\hline
\end{tabular}

${ }^{1}$ Membrane resistance.

compared with $\mathrm{R}_{\text {Foul.pi }}$, meaning that in this case the deposit layer contributed to a larger extent to the irreversible fouling. Irreversible fouling for the MF membranes studied was influenced to a larger extent by the pressure-independent fouling. This is a new finding because in previous studies the irreversibility of fouling was mainly related to the formation of a deposit layer. In this study, the relatively low transmembrane pressures prevented an exceedingly strong deposit layer compaction with higher degrees of irreversibility.

\section{CONCLUSIONS}

When skim milk is microfiltered using membranes with comparably low resistance, large parts of the membrane are dominated by a deposit layer even at low transmembrane pressures, resulting in low whey protein permeation. This is particularly true at the changeover from water to product at the start of production. By increasing the membrane resistance, the length-related local processing conditions for critical and limiting flux move toward to the membrane inlet. Therefore, the membrane area controlled by a deposit layer is decreased and the protein transmission increases at a lower permeate flow rate. Thus, for milk protein fractionation using microfiltration, for any membrane a certain filtration condition exists that leads to maximum specific mass flux of $\beta$-LG. The same should qualitatively apply for other protein solutions in a similar sense. These optimum conditions are reached at a certain relation of the local $\Delta \mathrm{p}_{\mathrm{TM}}$ and $\mathrm{R}_{\mathrm{M}}$. These findings should theoretically help to develop specific gradient permeability membranes for each fractionation task, where the membrane resistance is varied along the membrane to establish an isoflux situation across the whole membrane for the product to be filtered under certain processing conditions. Currently, this does not seem to be the case, because available gradient membranes appear to be developed based on isoflux for the filtration of water. Membranes with higher resistance allow filtration with a better control of the deposit layer.

\section{ACKNOWLEDGMENTS}

The authors are grateful for the financial support of the "Bundesministerium für Wirtschaft und Technologie (BMWi)" in the "Arbeitsgemeinschaft industrieller Forschungsvereinigungen" "Otto von Guericke" e.V. (AiF) within the project AiF-FV-Nr. $14740 \mathrm{~N}$.

\section{REFERENCES}

Altmann, J., and S. Ripperger. 1997. Particle deposition and layer formation at the crossflow microfiltration. J. Membr. Sci. 124:119 128.

Bacchin, P., P. Aimar, and R. W. Field. 2006. Critical and sustainable fluxes: Theory, experiments and applications. J. Membr. Sci. 281:42-69.

Beyer, H. J. 1990. Zum Einfluss der Proteinkonzentration auf das Denaturierungsverhalten der Molkenproteine sowie die damit verbundenen rheologischen Eigenschaften (The influence of protein concentration on the denaturation behaviour of whey proteins as well as the related rheological properties). Thesis. Technische Universität München, Weihenstephan. Germany.

Brans, G., C. G. P. H. Schroen, R. G. M. van der Sman, and R. M. Boom. 2004. Membrane fractionation of milk: State of the art and challenges. J. Membr. Sci. 243:263-272.

Bromley, A. J., R. G. Holdich, and I. W. Cumming. 2002. Particulate fouling of surface microfilters with slotted and circular pore geometry. J. Membr. Sci. 196:27-37.

Carić, M. D., S. D. Milanović, D. M. Krstić, and M. N. Tekić. 2000. Fouling of inorganic membranes by adsorption of whey proteins. J. Membr. Sci. 165:83-88.

Field, R. W., D. Wu, J. A. Howell, and B. B. Gupta. 1995. Critical flux concept for microfiltration fouling. J. Membr. Sci. 100:259-272.

Garcera, D., and E. Toujas. 2002. Graded permeability support for crossflow filtration. US Pat. 6,375,014; EU Pat. 0870 534; DE 698 00531 T2. Assignee, Societe des Ceramiques Techniques.

Gésan, G., G. Daufin, and U. Merin. 1994. Whey crossflow microfiltration performance using an M14 Carbosep membrane: Influence of initial hydraulic resistance. Lait 74:267-273.

Gésan-Guiziou, G., E. Boyaval, and G. Daufin. 1999. Critical stability conditions in crossflow microfiltration of skimmed milk: Transition to irreversible deposition. J. Membr. Sci. 158:211-222.

Gésan-Guiziou, G., R. J. Wakeman, and G. Daufin. 2002. Stability of latex crossflow filtration: Cake properties and critical conditions of deposition. Chem. Eng. J. 85:27-34.

Grandgeon, A., P. Lescoche, T. Fleischmann, and B. Ruschel. 2006. Crossflow filtration membran and its manufactoring (Querstromfiltrationsmembran und Verfahren zu ihrer Herstellung). EU Pat. EP 1074291 B1; DE 60023607 T2. Assignee, Tami.

Jimenez-Lopez, A. J. E., N. Leconte, O. Deheinault, C. Geneste, L. Fromont, and G. Gesán-Guiziou. 2008. Role of milk constituents on critical conditions and deposit structure in skimmilk microfiltration $(0.1 \mu \mathrm{m})$. Separ. Purif. Tech. 61:33-43. 
Kühnl, W., A. Piry, and U. Kulozik. 2008. Impact of membrane resistance on the filtration efficiency at the protein fractionation along micro filtration modules. Chem. Ing. Tech. 80:1199-1205.

Kuiper, S., C. J. M. van Rijn, W. Nijdam, G. J. M. Krijnen, and M. C. Elwenspoek. 2000. Determination of particle-release conditions in microfiltration: A simple single-particle model tested on a model membrane. J. Membr. Sci. 180:15-28.

Kulozik, U., and H. G. Kessler. 1988. Rinsing behaviour of deposited layers in reverse osmosis. Milchwissenschaft 43:784-789.

Le Berre, O., and G. Daufin. 1996. Skimmed milk crossflow microfiltration performance versus permeation flux to wall shear stress ratio. J. Membr. Sci. 117:261-270.

Le Berre, O., and G. Daufin. 1998. Microfiltration $(0.1 \mu \mathrm{m})$ of milk: Effect of protein size and charge. J. Dairy Res. 65:443-455.

Marshall, A. D., P. A. Munro, and G. Trägărdh. 1993. The effect of protein fouling in microfiltration on permeate flux, protein retention and selectivity: A literature review. Desalination 91:65-108.

Nakanishi, K., and H. G. Kessler. 1985. Rinsing behaviour of deposit layers formed on membranes in ultrafiltration. J. Food Sci. 50:1726-1731.
Piry, A., W. Kühnl, T. Grein, A. Tolkach, S. Ripperger, and U. Kulozik. 2008. Length dependency of flux and protein permeation in crossflow microfiltration of skimmed milk. J. Membr. Sci. 325:887-894.

Ripperger, S., and T. Grein. 2007. Filtration processes with membranes and its modelling. Chem. Ing. Tech. 79:1765-1776.

Samuelsson, G., P. Dejmek, G. Trägårdh, and M. Paulsson. 1997. Minimizing whey protein retention in cross-flow microfiltration of skimmed milk. Int. Dairy J. 7:237-242.

Tolkach, A., and U. Kulozik. 2005. Fractionation of whey proteins and caseinomacropeptide by means of enzymatic crosslinking and membrane separation techniques. J. Food Eng. 67:13-20.

Vadi, P. K., and S. S. H. Rizvi. 2001. Experimental evaluation of a uniform transmembrane pressure crossflow microfiltration unit for the concentration of micellar casein from skimmed milk. J. Membr. Sci. 189:69-82.

Zeman, L. 1983. Adsorption effects in retention of macromolecules by ultrafiltration membranes. J. Membr. Sci. 15:213-230. 